\title{
Problems of Using Texts with Unfamiliar Cultural and Social Context in English Language Learning ZAKIA NOOR MATIN
}

\section{Introduction:}

In English language teaching classrooms, teachers usually prefer to use foreign texts as teaching materials. Several reasons are there for this: first of all, language books which are published by the local publishers are not suitable for advanced students; secondly, teachers who are teaching English at university level are not interested in using those texts in the classroom. The teachers think that the texts are not good enough to be used at the university level, and they are not at all interested to write books suitable for English language classrooms, as so many foreign books are available in the market. At the same time when they search internet they get enough teaching materials. The problem arises when the students find that the social and cultural context they read about in the text is not familiar to them. This unfamiliarity with this context sometimes slows down the learning process though these texts help students to learn about different cultures and societies at the same time. Here one thing should be remembered that learning about other's culture and learning language through other's social and cultural context are different. My chief objective is not to teach students about different society and culture, rather it is to remove their scare about English language and make their way of learning smooth. This paper tries to show how unfamiliar social and cultural objects, which students get in their books, interrupts language learning; how this unfamiliarity with the context of the books creates scare in students mind; and how the students get away from contextual learning. Some books written by foreign writers and some handouts downloaded from internet which are being used in different institutions for English language teaching are taken as examples. I have also made a survey among the students and the teachers who are using these texts in their classrooms. This paper focuses on the English courses at the tertiary level. 


\section{What is context?}

By 'context' this paper intends to depict the situations or the facts we usually get from texts and it considers the social and cultural background and environment in which these situations or facts take place. Social background means the picture of a community where people share same custom and culture.

\section{Culture:}

Culture means the customs and beliefs, way of life, art and culture and social organization of a particular country or a group of people. It includes the attitude about something, like art, music, literature, festivals, clothing, food habit etc.

Now if we consider the social and cultural picture of foreign texts, we find that the society is not familiar to our students and they do not know much about that culture. Without any participation to other society, it is difficult to achieve skill of their language.

\section{The Role of Society and Culture in Language Learning:}

Language learning is a process for which a familiar environment is needed. In the book Ways with Words: Language, Life, and Work in Communities and Classrooms, Heath found that for children to get along with people and to accomplish social goals, they need to learn their community's language use, and they also acquire those ways of using language through experiences in various community activities and interactions. According to his suggestion, we find that, each community has specific ways of socializing members and helping them function in the community. In addition, there are several features in children's social and linguistic environments which vary strikingly from one community to the other. These features include:

. . . the boundaries of the physical and social communities in which communication to and by children is possible; the limits and features of the situations in which talk occurs; the what, how and why patterns of choice which children can exercise in their uses of language; and the values these 
choices of language have for the children in their communities and beyond. (Heath 144)

This is fact not only for learning mother-tongue but also for learning second language. "Language learning takes place at least partly as a means of social participation" (Goodman and Goodman 223-250).

\section{Who are the students?}

At the university level, students come from different social and cultural backgrounds. Students, coming from both English and Bangla medium institutions remain in the same classroom. The students who are from English medium institutions have less difficulties understanding the foreign texts. But those who are from Bangla medium institutions face trouble. The students who are from rural areas have to face even more difficulties. It is not possible to provide texts considering the cultural background of each student, but having the same national identity we have something very common, like food habit, clothing, customs, culture and forms of entertainment. When a student gets examples of unfamiliar name of any object, like food, dress etc, he or she tries to know the object first (whether it is a name of a food or dress), and then applies the grammar rules. In this way, the process becomes slow. Knowledge of cultural background is the prerequisite to read anything in other language and get it understood. Learning second language is a process in which the knowledge of language and the knowledge of cultural background are similarly important, and this knowledge will accelerate the process of learning. Through the study of other languages, students gain a knowledge and understanding of the cultures that use that language; in fact, students cannot truly master the language until they have also mastered the cultural contexts in which the language occurs (National Standards in Foreign Language Education Project 27). But within a very short time it is almost impossible to teach English culture and then English language.

\section{The Purpose of Introducing English Language Course at University Level:}

The purpose of introducing English language courses at the university level is to improve students' skill in this language so that they can communicate with people, 
understand their books, understand the class lectures and do well whenever they go abroad for higher studies and perform well at the job interview and build up a good career. So, the purpose is not similar to that of any institution where English is taught for making people able to get immigration VISA or any scholarship for higher studies. Now-a-days, people feel the necessity of learning English for daily communication for different purposes. But it does not mean if we want to learn English, we need to learn it from English cultural context. From classroom experiences it is seen that sometimes students do not feel any attachment to the language when they feel English as an alien language. Besides, in our country English is used mainly for professional purpose not for interpersonal communication.

\section{The Problems Using Foreign Texts in the Classroom:}

A familiar environment enhances language learning process; for example, in the classroom if students are told to write a paragraph on "Football", most of them can easily write on it, but if they are told to write on "Baseball" very few of them will be able to do it. There are some limitations to use foreign texts in classroom. From my observations of English language teaching classrooms at the class hours, the following problems are identified. These classrooms were basically language classrooms of different departments, like Computer Science, Business Administration, Microbiology, Electrical \& Electronics Engineering and Law of Stamford University Bangladesh. These courses were conducted by me at different times.

\# The use of unfamiliar objects as examples create confusions in students' mind.

\# Sometimes gender cannot be identified by name.

\# Sometimes things cannot be identified by name.

\# Stories based on different culture create uneasiness and distract attention from the ultimate goal.

\# Sometimes some stories of these books, based on different cultural incidents create a conflicts in students' mind regarding social values and norms. 
\# These texts sometime create inhibition about English language in students' mind.

\section{Sample Materials:}

The first limitation of these tests is using unfamiliar objects as examples. It is very natural that while writing a book for language learners, a writer will take maximum examples from his surroundings. The writer usually considers the status of his or her students. But when this book becomes a text for students of different culture and countries, the problem arises. These students might not understand the examples where the unknown objects are used. For these reasons, the subjects might not be clear to them if they don't understand the examples. Some examples are taken from English Skills by John Langan, New Headway Pre-Intermediate Workbook by John and Liz Soars and some handouts taken from internet. How students usually deal with the situation is shown from classroom (previously mentioned) observations.

\section{Problem 1:}

In the chapter of Pronoun Reference in English Skills, by John Langan an exercise is given, like 'I love parmesan cheese on veal, but it does not always digest well' (479). The name of the food was quite unfamiliar to most of the students of our country. They got confused of what they would answer instead of which noun, parmesan cheese or veal. They did not know which one, parmesan cheese or veal or the combination was not digesting. In the same chapter some names were used which created confusion in students' mind. In another exercise, like 'The flakes in this cereal (taste, tastes) like sawdust', students were told to use suitable verb. Students often became confused whether they would use 'taste' or 'tastes' as most of them did not have the idea whether flakes were countable or uncountable. Students often face difficulty while solving these exercises. In one of the exercises of the Headway Workbook, students were told to put appropriate verb where a sentence, like 'When I was young I always __ turkey on Christmas' (18) was given. Most of the time students put the verb 'visited' because they knew Turkey as a name of a place, not as a name of food. They became so confident that they did not even 
notice that the word was written in small letter. The names of some hard drinks, like champagne, wine which are uncommon for the students of this level caused the same problem. Again in another exercise, 'Packed tightly in a can, Fred had difficulty removing the anchovies', students were told to correct the dangling modifier. They did not have any idea about the word anchovies, and therefore, they could hardly correct this problem.

\section{Problem 2:}

In a reading text, the name of the protagonist was June. The students were told to answer some questions. Some of them wrote "she" for June and some of them wrote "he". In the chapter for pronoun reference students have to use proper pronouns for some names, and they didn't know whether they will use he or she for these names, like Lin Soo, Bob, Shirley, June, Margie etc.

\section{Problem 3:}

Sometimes the names of different festivals, organizations, vehicles etc. are used for work-sheets which require pre-knowledge regarding these. For example, in Headway Workbook, a listening test is given where a plumber won a lottery and bought a Porsche. Nowhere it is mentioned that Porsche is a name of an expensive car. And those who do not know this fact face problem while answering the questions. It is good if they get informed about any unknown object through exercises, but it becomes a problem if any exercise requires pre-knowledge about a particular object. In the same book an exercise is given, like 'Rolls Royce cars

(is/are) made in Japan' (13), where students were being informed about Rolls Royce.

\section{Problem 4:}

Another problem of these texts is that sometimes the books involve some stories or facts taken from foreign contexts, which create cultural conflict. Some parts of a text are taken as example. 
A second benefit of the club is that it helps me realize how similar people are. When the whole club first assembled, we wound up having a conversation about dating and sex that included the perspectives of fifteen countries of six continents! It was clear we all shared the feeling that sex was fascinating. The talk lasted for hours, with many different persons describing the wildest or funniest experience they had had with the opposite sex. (Langan 94)

The text is about a college multicultural club, and the writer is telling about his experience after joining there. His speech gives some ideas about the multicultural clubs. In our context, the idea of college's multicultural club is quite different. Here people are conscious about national politics, international politics, social crisis, economy, media, day to day incidents and some other things, but this is quite unfamiliar to us that being members of a cultural club people are sharing their wildest and funniest experience of having sex. When a teacher lets students solve this exercise (putting appropriate transitional words), he or she gets into a problem. Student's concentration goes to the subject matter instead of solving the problem carefully. Their attention gets away from the main point. In another book, a text is titled as "Phoning a Dating Agency" where a girl named Cathy has recently moved to London to start a new job. She wants to join a dating agency to find a boyfriend. After knowing about this agency the students became very curious, and the curiosity was not about the problem to be solved but about an agency which helped people to get boyfriend or girlfriend for dating. In the same book a text for reading test is titled as "Blind Date" where Matt is looking for a girlfriend for a week. A magazine named Evening Star helps a single person choose the perfect partner and have a date in an expensive restaurant. Then photographs with profile information of three girls are given and students are questioned as, "Who do you think Matt will pick from these three lovely girls?" (11). Definitely students get interested about these western cultures, but teachers have to consider what type of interest is this. This interest may become harmful for their cultural value.

\section{Problem 5:}

In chapter eighteen of the same book, a text named "Full Circle" is given for reading practice. There a speaker is telling how his sex life has come to a 
fulfillment. Though nothing is immoral with the content of the text and the writer's intention is not to tell anything pervasive, the picture of the society and the life style of teen-agers we get from the story conflicts with our society. It is quite normal with an English society that a boy of fourteen is frequently going out on dates with several girls, enjoying "Saturday Night" serial and having sex (Langan 312), but in our society it is still not that much normal. The picture is conflicting with our social value system and goes against our social norm and culture. It is not being told that university-going students do not have any idea about dating, girlfriend or boyfriend, but that should not be included in the texts for language learning. When students are told to read the story and answer the questions, what moral lesson they will learn and what skill they will achieve. As they are still not skilled in reading, it is hard for them to understand the moral of the story. They might be misguided by the story, and the description, the writer has given about his dating might be stimulating rather than educative. Besides, text should not be based on something which creates conflict with our social value system.

Now a question may arise that should the texts be limited by our own social and cultural context. Cultural information should not be presented in a way where students get differences between the students' native culture and the culture explored in the classroom. Kramsch in Context and Culture in Language Teaching, describes the "third culture" of the language classroom- a neutral space that learners can create and use to explore and reflect on their own and the target culture and language.

\section{The Survey:}

For a questionnaire survey, one hundred students and ten teachers have been selected from three private universities in Dhaka, Bangladesh in January, 2011. The universities surveyed are Stamford University Bangladesh, Daffodil International University and University of Liberal Arts. The students were from Business Administration, Electrical \& Electronics Engineering and Pharmacy departments who were doing English Fundamental and Composition courses. 
There were separate questionnaires for students and teachers. The questionnaire for the students contained 13 questions, and the questionnaire for the teachers contained 9 questions. The respondents choose their answers from multiple choices. However, options were provided for making more than one choice. Respondents could also answer in written if the options were not enough.

\section{Evaluation of the Survey Result of the Students:}

The survey results are discussed below according to the order of the questions in the questionnaire. For the first two questions, 100\% students answered that they used a particular text in the classroom and the texts were written by foreign writers. In the third question students were asked whether they understood all the exercises given in the text or not. $40 \%$ of them answered positively, $10 \%$ answered negatively and $50 \%$ said not always. For the next question, 50\% students answered that they did not always enjoy the text given in the book for reading comprehension. $30 \%$ answered positively and $20 \%$ answered in negative. In question 5 students were asked whether they got any similarity between the culture they were getting from the text and their own culture. $80 \%$ students answered that they did not always get similarity, 20\% answered "yes". Next question was if they enjoyed learning English through other's culture, and $40 \%$ said "yes", $40 \%$ said not always and 20\% said "no". In question 7, they were asked if they could identify gender by the name of a person which they got in the books. $60 \%$ could not always identify, $40 \%$ could always identify. The next question was regarding the name of food, dress, drink, any agency or organization, any festival or occasion. $65 \%$ answered that they did not always understand, and 35\% answered that they always understood. In question 9, students were asked if they thought that examples or exercises where unknown object was used sometimes interrupted their attention to language learning. $60 \%$ answered "sometimes", 30\% answered "never" and 10\% answered "always". In question 10, they were asked whether they felt easy with the foreign text or not. 50\% said positively, 35\% said "not always" and 15\% said "no". In the question 11 , they were asked what they usually did if they faced any problem while doing the exercises. $60 \%$ students answered that they asked their teachers when they did not understand any word. 30\% answered that they consulted dictionary and $10 \%$ answered that they skipped that part. In the next question, they were 
asked if they think it would be better if exercises were designed with familiar objects. 85\% answered "yes" and 15\% answered "not needed". Next question was whether these texts created any scare in their mind about English or not. $40 \%$ answered positively and $60 \%$ answered negatively.

From the answer of these questions, it is clear that most of the students felt that the foreign texts which they used in the classroom sometimes created interruption to their learning. The students are not from same social background and most of them are from middle class and upper middle class society. So, without having any introduction of foreign society and culture, if they start using these texts in the classroom, they will feel uncomfortable with the context. For this reason maximum students choose the answer "not always". The $60 \%$ answers of the questions 11 and 12 imply that if they can learn with the examples of common objects, they will feel comfortable. The answer of question 13 shows that though most of them felt uncomfortable, they were not scared, but the answer of this $40 \%$ should be considered. If $40 \%$ or even less than $40 \%$ think that it is scaring, it may hamper the learning situation.

\section{The Result of Teachers' Survey and Evaluation:}

From the teachers' survey result we got that all of them suggested more than two reference books for classroom practice, and all of them were written by foreign writers. In question 3, they were asked whether their students understand the text properly or not. All of them answered "not properly". The same type of question was asked whether their students felt comfortable with the foreign texts or not. $70 \%$ answered negatively. Fifth question was from which social class their students came from. All of them answered "from middle class". In the next question, they were asked what they usually did if student did not have any idea about an object. $80 \%$ teachers answered that they tried to give a little information about the object. In the seventh question, they were asked whether an unfamiliar object, used as an example interrupted the learning process or not. Six teachers said "sometimes" and four teachers said "no". In the next question they were asked if they supported the texts to be written in our context. 8 teachers agreed but 2 teachers said, "Not necessary" and the reason behind their answer was the problems created by these 
texts were not that serious. When they were asked why they choose the texts written by foreign writers, they answered that the books written by local writers were not good enough. The last question was if they found anything which was completely opposite to our social value, and what they usually did then. $60 \%$ answered positively and said that they skipped that thing, 30\% answered that they tried to say their students that those were not our culture, and 10\% answered that they ignored other effect. This $60 \%$ answer implies that some parts of the text are not suitable for practice.

\section{Some Suggestions:}

\section{Brook states:}

Turning to culture, we deliberately shift focus away from language as such towards the people who use the language: where and how they live, what they think, feel and do. It is nowadays a commonplace in language pedagogy that language and culture are intertwined, that it is not possible to teach a language without culture, and that culture is the necessary context for language use. (45)

But we are not learning English to use it in English environment, rather to use it in our professional and educational environment. So the field where we are going to apply English should be explored first, and that will be the necessary context for language. If we learn English to use it in the foreign environment, it will be necessary to learn about their culture, and that learning is the pre requisite for language learning. However, the duration of the courses in university level is so short that it is difficult to learn about a different culture before learning language. The following suggestions can be followed:

\# Reference books and handouts for English language classes can be selected according to the level of the students.

\# The fields of applying English language should be explored first and accordingly exercises can be designed.

\# The objects which are used in the exercises should be taken from our surroundings. 
\# The facts or the story selected for reading practice can be based on our day to day incidents.

\# Concepts taken from different culture can be presented in an informative way. For example, if students are given an exercise, like "Halloween is by the Americans", students will not be able to put the correct word. But if it is given in a way, like "Halloween is a festival by Americans", the students will be able to know about a new thing and answer it properly.

\# Teachers should not use any teaching material which goes against our social value. In an article on discourse, for example, Brown questions whether or not language may be value-free or independent of cultural background. She concludes: "There are values, presuppositions, about the nature of life and what is good and bad in it, to be found in any normal use of language" (17). Such normal language use should be the aim of language teacher.

\# Teachers can take initiative to write books for students of the university level and make more research on it. In the universities of our neighboring country India, books written by local writers are being used as reference texts. If we suggest our students to use books by local writers, more writers will be motivated to publish books for the students of university level.

\section{Conclusion:}

Research is being made from various levels to find out ways to improve students' communication skills in English. But not that much concentration is being given on the text-books. More concentration should be given on text books. At the university level, students do not get much time to study and practice English language. Teachers should be conscious about selecting text book. The text should be interesting, comfortable to practice and educative so that even after class hours their interest to work with the exercises still remains. A familiar environment plays an important role to make the language learning process effective. On the other hand, if students get a known picture of society and culture from book, their uneasiness of learning foreign language will be removed. 


\section{Work Cited}

Brooks, G.L. Varieties of English. London: Macmillan Press, 1964. Print.

Brown. G. “Cultural Values: The Interpretation of Discourse.” ELT Journal 44.1 (1990): 11-17. Print.

Goodman, Y. M. \& K. S. Goodman. Vygotsky in Education: Institutional Implications and Applications of Sociohistorical Psychology. Cambridge: Cambridge University Press, 1990. Print.

Heath, S.B. Ways with Words: Language, Life, and Work in Communities and Classrooms.

New York: Cambridge University Press, 1983. Print.

Kramsch, C. Context and Culture in Language Teaching. Oxford: Oxford University Press, 1993. Print.

Langan, John. English Skills. 7th ed. New York: McGraw-Hill, 2001. Print.

Soars, John, Liz Soars, and Sylvia Wheeldon. New Headway Pre-Intermediate Workbook. Oxford: Oxford University Press, 2011-12. Print.

National Standards in Foreign Language Education Project. "Standards for Foreign Language Learning in the 21 st Century." New York: American Council on the Teaching of Foreign Languages (ACTFL), 1996. Print. 


\section{Appendix 1}

Name: Name of Institution:

Department:

This simple questionnaire asks for your opinion about language books. Please put a tick mark for appropriate answer.

1. Do you follow a particular book for the language class?
(a) Yes
(b) No

2. This book is written by-
(a) Foreign writer
(b) Local writer

3. Do you understand all the exercises given in the text?
(a) Yes
(b) No
(c) Not Always

4. Do you enjoy the texts given for reading practice?
(a) Yes
(b) No
(c) Not Always

5. Do you get any similarity between the social and cultural elements of your text and your own?
(a) Yes
(b) No
(c) Not Always

6. Do you enjoy learning English through other's culture?
(a) Yes
(b) No
(c) Not Always

7. Can you easily identify gender from the name of a person which you get in your text?
(a) Yes
(b) No
(c) Not Always

8. Can you identify food, dress, drinks, organizations, any festival or occasion?
(a) Yes
(b) No
(c) Not Always

9. Do you think that unknown social and cultural objects interrupt your attention?
(a) Always
(b) Sometimes
(c) Never

10. Do you feel easy with the foreign text?
(a) Yes
(b) No
(c) Not Always

11. What do you usually do when you face any problem while solving exercises?
(a) Asking Teacher
(b) Consulting Dictionary
(c) Skipping the Part 
12. Do you think it is better to use familiar objects for the exercises?
(a) Yes
(b) No
(c) Not Needed

13. Does this text create scare in your mind?
(a) Yes
(b) No

\section{Appendix 2}

Name: Designation:

Institution:

This questionnaire is about texts you follow in the language classroom. Put tick mark for the correct answer.

1. Do you use a particular book in your classroom?
(a) Yes
(b) No

2. Is it written by foreign writer?
(a) Yes
(b) No

3. Do your students understand the text properly?
(a) Yes
(b) No
(c) Not Always

4. Do your students feel comfortable with the text?
(a) Yes
(b) No
(c) Not Always

5. From which social class do your students come?

(a) Upper or Upper Middle

(b) Middle and Lower Middle

(c) Lower

6. What do you usually do if students do not have any idea about an object? Ans:

7. Does an unfamiliar object used as an example interrupt learning process?
(a) Yes
(b) No
(c) Sometimes

8. Do you think language text written from our social and cultural context should be selected for language classroom?
(a) Yes
(b) Not Needed. Explain the reason: 
9. Do you find anything in the text which is completely opposite to our social value?
(a) Yes. What do you usually do?
(b) No

10. Ans: 